\title{
The other Foot in George Farquhar's: The Beaux Stratagem
}

\author{
Adil M. Jamil
}

Amman Arab University, Amman. Jordan.

\begin{abstract}
This article is designed to highlight the innovation of George Farquhar in his play The Beaux Stratagem, and to illuminate the factors behind its everlasting appeal to audiences since its first performance in 1707 and after. The play still retains a magnificent appeal to all audiences for centuries, and remains alluring and fascinating to even the $21^{\text {st }}$ Century audiences. Its magnitude lies in the sure-fire comic devices and witty characters as well in the profound insight adjoined the comic situations and events. As a transitional playwright, Farquhar has one foot in the declining traditions of the Comedy of Manners, and the other foot in the growing vogue of Sentimental Comedy, employing some character types of the old tradition with innovative alteration, together with introducing prototypes of the coming sentimental types. To keep pace with the shift in tone, he modifies the purpose of his play to suit the specifications of critics, moralists and theatre goers. With its innovative particulars, it sets an early premise for the approaching changes in the dramatic conventions and trends of the $18^{\text {th }}$ Century comedies. More crucially, it forms a gateway to move into the world of sentimentalism, or a bridge between the two.
\end{abstract}

Keywords-George Farquhar, The Beaux Stratagem, Comedy of Manners, Sentimental Comedy, Innovation of English Comedy.

\section{INTRODUCTION}

Farquhar' play The Beaux Stratagem, has been a huge success since its first performance in 1707 on the Theatre Royal in London. It was performed more than six hundred times in the $18^{\text {th }}$ Century (Kenny 1988), and has remained a favorite dramatic piece of entertainment up to the $21^{\text {st }}$ Century. Many theatric and academic groups have performed the play in its original text or with some modification, but mainly the spirit of Farquhar remains intact. Among critics, the play keeps hovering between high estimation of its comic spirit, and adverse ideas related to its plot. In all measures, the events in The Beaux Stratagem are neatly contrived, yet with some notable setbacks. Like an old tale, the plot relies upon coincidences (Hume 1976, Bevis 1997, Canfield 2001). For instance, it is a mere coincidence that Archer is in the house at the time of robbery. It is also a sheer coincidence that Archer strikes out of the blue upon the name Mackshane Foigard, and this forces Foigard to tell the secret he shares with Gipsey, planning to rob the house of Bountifuls'. Another coincidence is employed at the end of the play: Lord
Aimwell dies unexpectedly, and his younger poor brother Aimwell inherits the title and estate of his deceased brother and happily marries Dorinda. It is also coincidental that Gibbet steals the papers of Mr. Sullen and then those papers fall into the hands of Archer. This coincidental theft grants Mrs. Sullen divorce and gives her the power of law to get her money back from her boorish husband. With this defect, adverse criticism comes to an end.

At large, the play always draws warm reception from theater-goers. Most critics acknowledge its sure-fire comic devices and witty characters, and the innovation and literary contribution of Farquhar to English Comedy. With its innovative particulars, it set an early premise for the approaching changes in the dramatic conventions and trends of the $18^{\text {th }}$ Century comedies. More crucially, it formed a gateway to move into the world of sentimentalism, or a bridge between what preceded and what came after.

Farquhar is actually a transitional playwright standing between the Comedy of Manners and the Sentimental or Exemplary Comedy. He wrote The Beaux Stratagem, seven 
years after Congreve's most popular play, The Way of the World, performed on stage in 1700. Farquhar's play comes out as an admixture of Congreve's temper and the increasing vogue of sentimentalism in English comedies. He neither splits completely with the traditions of Restoration comedies nor entirely adheres to the new traditions. His brilliant blending of the two genres encourage critics to see Farquhar a peculiar playwright, having a foot in both, the ending world of comedies of manners, intrigue and farce, and another foot in the rising vogue of sentimental or exemplary comedy. John Wilson comments,

The Beaux Stratagem is invariably successful because it is made up of sure-fire comic devices and characters, and because it has a mildly sentimental ending. As the last writer of Restoration intrigue comedy and one of the first of the new eighteenth-century sentimental dramatists, Farquhar was a transitional poet with a foot in both worlds. His comedies are neither satiric nor witty, but they are wellplotted, genuinely amusing, genial, and humorous (Wilson: 1965, 146-147).

In the light of Wilson's and others', it could be said that Farquhar's work is a fusion of both the Restoration dramatic traditions and the newly rising sentimental vogue. Many critics commend his peculiarity and notable distance from the playwrights who came before and after The Beaux Stratagem. Dobree (1966), for instance, marks the uniqueness of Farquhar as follows,

Farquhar, it is true, commented upon manners, but such criticism was only a side issue with him. He was more intent upon lively action and the telling of a roguish tale. It is all fun and frolic with him, a question of disguise and counterfeits, the gaining of fortunes, and even burglarious entries. This is the real spirit of Farquhar, a huge gust of laughter... Life was a disgusting and painful thing to him, and the only remedy was to treat it as a game, not the delicate intellectual game of Etherege, but a good Elizabethan romp $(162,167)$.

William Archer, one of the ardent admirers of Farquhar, launches thorough comparisons between Farquhar and his contemporaries and predecessors. To Archer, Farquhar has a sweeter, cleaner, healthier mind than Congreve and Wycherley. He sees Farquhar more humane, and more inclined to display greater moral standards than most of his contemporaries. Beside moral standards, his dialogue is more natural than others'. In his plays, natural humor takes the priority over wit or cynical retorts customarily seen in
Restoration comedies. To Farquhar, wit should either naturally come off, or it should not be forced. In other words, if wit comes not naturally as it should, it had better not come off at all:

Farquhar reduced wit within something like the limits of nature, subordinating it to humor, and giving it, at the same time, an accent, all his own, of unforced buoyant gaiety (Archer and Strauss, 24).

\section{A FOOT IN RESTORATION COMEDIES}

In truth, Farquhar's plays were written at a time when the early exuberance and rakish irreverence of Restoration comedy beginning to give way to a more sentimental and moralized comedies. More possibly he made out that his audience had a change of heart, and no more interested in what a traditional comedy of manners and intrigues offer. For such convictions, Farquhar curbed the natural bent toward wit and tried to engage a more sentimental side instead. As implied above, The Beaux Stratagem neither completely overlooks the declining traditions and vogues common in the plays of his elders, nor entirely adopts the rising traditions of the $18^{\text {th }}$ Century. Farquhar makes use of the common traditions of Restoration comedy, albeit with some alteration, and concurrently introduces innovative devices that anticipate the upcoming changes in English Comedy. In The Beaux Stratagem, Farquhar employs the same character types customarily seen in the comedies of his predecessors Etherege, Wycherley, and Congreve, yet he brilliantly modified and further developed those types to be more amusing and appealing to the audience of his time. The character types, Farquhar employs, sound more typical and better examples than those encountered in other Restoration plays, as evident in the following sections:

\section{Country Squire}

Farquhar introduces one of the best examples of a country squire, a character type, most often surfaces in earlier comedies of manners and intrigues. Mr. Sullen, the country squire, is attributed with memorable traits like others, yet greatly modified to look more genial and humorous. Like Sir Willful in Congreve's The Way of the World, or Sir Jasper and Pinchwife in Wycherley's The Country Wife, Mr. Sullen is fond of drinking, the trade mark of most country squires. His wife, Kate, describes his penchant as follows:

He came home this morning at his usual hour of four, wakened me out of a sweet dream of something else, by 
tumbling over the tea-table, which he broke all to pieces; after his man and he had rolled about the room, like a sick passenger in a storm, he comes flounce into bed, dead as a salmon into a fishmonger's basket. (II.i.71-77)

In addition to drinking, blockheadedness and sluggishness are other common attributes attached to Squire Sullen. Bonniface, the landlord of the inn, where the main characters Aimwell and Archer reside, once gives a better insight of this country squire: [Mr. Sullen] says little, thinks less, and does nothing at all, and adds, But he's a man of a great estate, and values nobody (I.i.99-101). Though alcoholic, boorish, and unthinking, he is a man of pleasure; he plays whisk [cards] and smokes his pipe eight and forty hours together sometimes (II.i.103-105). This card player and inveterate pipe smoker is yet a sad brute. He spends long hours with low company as Bonniface explains to Sir Charles:

Freeman: Is Mr. Sullen's family a-bed, think 'e?

Bonniface: All but the squire himself, sir, as the saying is-he is in the house.

Freeman: What company has he?

Bonniface: Why, sir, there's the constable, Mr. Gauge the excise man, the hunchbacked barber, and two or three other gentlemen. (V.i.8-19)

Furthermore, Farquhar's Squire has a tendency to act and behave like city people in relation to his wife and in relation to the concept of honor. He is excessively an indifferent husband, neglecting completely whatever his wife does. By contrast, he cares only about the appearance of honor, like most hypocrites in the Beau Monde community. Like Sir Jasper Fidget, the cuckold, in The Country Wife, Squire Sullen pays the least of attention to the flirting of his wife, provided her extramarital affair is kept concealed, and his public image remains untarnished. On the occasion of finding Count Bellair courting Kate, he raves at the Count and his wife, yet the reason behind his rage is not foreign to his early counterparts':

Look' ee, madam, don't think that my anger proceeds from any concern I have for your honor, but for my own, and if you contrive any way of being a whore without making me a cuckold, do it and welcome. (IV. i. 436-440)

Like a city cuckold, Mr. Sullen is willing to tolerate her flirting only if she keeps it away from others' notice. Kate, his wife, perhaps goes by the recommendation of Lady Fidget's advice: Who for business from his wife will run/ Takes the best care to have her business done (The Country
Wife, II. i. 619-620), and she has a reason to do so. For being battered and neglected, Mrs. Sullen revenges her indignation by debauchery and flirting, however with no avail since Mr. Sullen gives a blind eye to what she does in private. He is a country squire for sure, yet acts and behaves like a newly initiated city gentleman, infected by the social diseases of the Beau Monde.

\section{Gay Couple/ Serious Couple}

In addition to the country squire, the play provides one of the funniest examples of a gay couple together with a serious couple. On one hand, Archer, who assumes the livery of a servant to Lord Aimwell, and Mrs. Sullen, a comely London Lady and unhappily married to Squire Sullen, are a grand example of a gay couple. Their humorous repartees are largely witty, genial, and sometimes risqué, as is the common repartee of traditional gay couples if not better. On the other hand, Aimwell, a Londoner who comes to Lichfield and poses as his elder brother Lord Aimwell, together with Dorinda, a wealthy heiress, represent the serious couple. These two soon grow earnest in their pursuit of decent marriage, more probably like Mirabell and Millamant in Congreve's The Way of the World. Furthermore, while Aimwell, the protagonist, acts like a rake at least when he first meets Dorinda, he displays attributes different from those of typical Restoration rakes. Unlike most gay and witty rakes, Aimwell is graver than Mirabell, yet less witty, less rakish, and obviously more sentimental. However, his exclamations on coming out of an affected fit breach the outward manifestation of sentimentalism in his character:

Aimwell: Where am I? Sure I have passed the gulf of silent death. And now I land on Elysian shore-- Behold the goddess of those happy plains, Fair Proserpine: let me adore thy bright divinity. (Kneels to Dorinda and kisses her hand)

Aimwell earnestly continues his rant entreating Dorinda, the lady he desires to take as a wife, and further carries his rant to excessive lengths:

How could thy Orpheus keep his words and not look back upon thee? No treasure by thyself could sure have bribed him to look one minute off thee. (IV.1.185-195)

\section{Label Names}

Like other playwrights of the comedy of manners and intrigues, Farquhar retains the same tendency of giving label names to his characters. Archer and Aimwell are given typical label names. Both names suggest fortune hunters, 
hunters of women, Cupid and love. These two names are also closely connected to the title of the play. Beaux can allude to bow, and stratagem is related to love, in that Cupid is known for planning stratagem, whereas Aimwell is in the habit of aiming only at the right target. Other characters are given label names too. Mr. Sullen's name suggests gloomy, morose, and dismal person with disagreeable moods. Lady Bountiful's given name suggests generosity and openhandedness; she is an old civil, country gentlewoman, often volunteering to cure her neighbors of all distemper, yet she is foolishly fond of her son, Mr. Sullen. Sir Charles Freeman is a Londoner gentleman, coming to free his sister from a brute husband, and the connection between his given name and his conduct is quite perceptible. The same can be said about the given names of Gibbet, a highwayman, and his associates Hounslow and Bagshot. Clearly each given name has something to do with the nature and profession of its bearer, as is the case in other Restoration comedies, for instance Mr. Horner, Lady Squeamish, Lady Fidget, and Sir Pinchwife in Wycherley's The Country Wife; Mirabell, Millimant, Lady Wishfort, Sir Willful, Mr. Fainall, and Foible, in Congreve's The Way of the World; and Mr. Medley Sir. Fopling, Lady Woodvill and Loveit in Etherege's The Man of Mode. All these are label names given to specific characters with a related conduct.

\section{THE OTHER FOOT OR THE INNOVATION OF FARQUHAR}

Though Farquhar retains some traditions of the Comedy of Manners and Intrigues, he sounds more innovative in The Beaux Stratagem. The innovation of Farquhar can be detected in the setting of his play, the new purpose of comedy he adopts, the role assigned to low characters, the blending of high and low worlds, the alteration he makes in the portrayal of chief characters, and the earnest discussion of marriage and divorce. The following sections illuminate Farquhar's innovation and literary contribution:

\section{Locale of Events}

Farquhar's first notable split with the common traditions of contemporary playwrights lies in the locale he gives to his play. He moves the locale of events from the traditional harbor of Restoration comedies, the city to the country. He set The Beaux Stratagem in the country rather than the city drawing rooms, the city parks, or malls, the traditional locales of the typical Restoration comedies of his time. All the events in Farquhar's play take place at a country inn and a close-by country house. The two major characters, Aimwell and his friend Archer are taken from the city, London, and brought to Lichfield, the heartland of the country looking for a country wealthy heiress to fill their empty coffer.

\section{Purpose of Comedy}

The second notable split lies in the purpose of The Beaux Stratagem. As common, the beginning of the $18^{\text {th }}$ Century witnessed a growing shift in tone toward Restoration comedies (See Hume 1976, Hughes 1996, Cordner 2000, and Gosse 2004). The new shift received some impetus from the increasing criticism of many moralists and even from some playwrights. Jeremy Collier, the self-appointed paragon of morality, launched a severe attack on the whole enterprise of theater (Rose 1966, Kaneko 1997). Long before Collier, the playwright Shadwell took aim at the Comedy of Wit, particularly its immorality. Shadwell vocally resented the publicity of obscenity, sexual explicitness, vices, and risqué language of Restoration comedies, and often called for a moral reform in drama (Armistead 1984, McMillan 1997, Nicoll 1965). In addition to Collier's and Shadwell's, the attitude of women had a hand in the campaign against the immorality of Restoration comedies. Women, actually formed the great bulk of theater goers and their response was highly considered by authors and producers. To the end of the $17^{\text {th }}$ Century, women's response grew more critical of the theme of libertine seduction, cuckolding, infidelity, frailty of females, rakish behavior, and coarse language of comedies. Such attitudes pressured playwrights to modify the tone, language, and trends in their plays. Many playwrights devise dramatic situations and language that suit women's specifications in particular (Nicoll: 1965, Dobree: 1966, Bevis: 1997). In additions, one may assume that theater goers in general were fed up with what became a boring stereotype, repeatedly showed on stage for three decades though in different forms and guises. Having or not having a wit, the used-to-be a favorite theme, was no more a point of attraction or a source of laughter. The reminiscent schemes played by a rake upon helpless women was no more appealing as before. The audience had a change of heart and anxious to see something different on stage. In response to the moralists and theater goers, the purpose of comedy took a new turn in the $18^{\text {th }}$ Century: it is no more for entertainment sake only; comedies, supposedly, became a 
medium of instructions too, not only to amuse but to instruct and give lessons. Such trends formed a major shift in the purpose of comedy.

Farquhar soon felt the shift in tone and insightfully responded. His play The Beaux Stratagem renders a different purpose, perhaps responding to the growing debate on the purpose of comedy by critics, influential moralists, and theater-goers. While other playwrights continued playing up burlesque and mockery and playing down instruction, Farquhar adopted new trends, and embraced the idea that the sole purpose of comedy should not be only entertainment, but also instruction. Both should go hand in hand in a comic presentation. His inclinations to instruct while entertaining soon found their way to the comedies of his contemporaries and also to the comedies of Sentimental Age in which the blending of instruction and entertainment became customary.

Equally important, one may infer that Farquhar's moving the comedy setting out of the city into the country is apparently done for an instructional purpose. More likely, his move is meant to provide a more realistic image of the country and its people, an image often distorted by Restoration playwrights. Both William Archer and Louis A. Strauss in their introduction to the edition of The Beaux Stratagem commend Farquhar's skills for brilliantly portraying,

the life of the inn, the market place, and the manor house. He showed us the squire, the justice, the highwayman, the innkeeper, the recruiting office, the country bell, the chambermaid, and half a score of excellent rustic types. (Archer \& Strauss 24)

The portrayal of the country in The Beaux Stratagem is different from what the audience was accustomed to see in Restoration comedies. The country is neither entirely fascinating nor completely disdainful. Like the city, it comprises the virtuous and the vicious, the intelligent and the blockhead, the witty and the dull, the brute and the kindhearted. In The Beaux Stratagem, some citified characters express distain and contempt to the country and its people, yet others express a different attitude. For example, Mrs. Sullen mocks the idea of leaping of ditches, and clambering over stiles (II.1.33), and adds when a man would enslave his wife, he hurries her into the country (II.1.33-34). However, her unpleasant assessment of the country can be taken as merely an individual case, especially if we know that Kate Sullen is a London lady whose fate has recently thrown her into the lap of a vicious country squire. Mr. Sullen, a boorish and rude, displays the ignoble norms of some country people. Opposed to Sullen, some country individuals are decent enough to offset the contemptible attitude held by city people toward all country and its people. Dorinda, a country lady, is fresh and intelligent. Like Harriet in Etherege's play The Man of Mode, and Millamant in Congreve's The Way of the World, Dorinda is so compassionate and possesses no less charm and far more wit and worldly wisdom than her counterparts. Lady Bountiful, a country lady too, is philanthropic and ready to kindly and generously serve her neighbors. At large, Farquhar seems more "sensitive to the charms of simple country life than his contemporaries do (Stone 349), and his presentation of both sides is meant to rectify the common attitude wrongly publicized on stage by other playwrights.

\section{Role of Low Characters}

The role of low characters is modified too in The Beaux Stratagem. The low characters, country boobies and servants, are assigned more important roles than that given before to country boobies such as Sir Willful, in The Way of the World, or Pinchwife and Sir Jasper in The Country Wife. The introduction of low, yet important characters, is another notable contribution. Farquhar employs and develops bewitching personalities of new types. Both Mr. Bonniface, the country innkeeper and his daughter Cherry, a great favorite to audiences, give expression to the genial side among low characters. Both are insightful, witty, and cheerful. Their vivid presentation is quite appealing not only to theatre goers, but also to several $18^{\text {th }}$ Century playwrights. Following the footsteps of Farquhar, Goldsmith later used the idea of an innkeeper and his daughter to complicate the case of a mistaken identity in his renowned play She Stoops to Conquer (Jeffares 2002). Gibbet, another low character, is portrayed as an entertaining rogue whose witty remarks and gay retorts add an amusing flavor to the play. When Archer claps a pistol to his breast and says, Come, rogue, if you have a short prayer, say it, Gibbet wittily retorts, Sir, I have no prayer at all; the government has provided a chaplain to say prayers for us on these occasions (V.iii.184-188). Another instance of freshness and high spirit can be detected in Gibbet's remark to Bonniface about Cherry,

Look 'ee, my dear Bonny-Cherry 'is the goddess I adore,' as the song goes; but it is a maxim that man and wife should 
never have it in their power to hang one another; for if they should, the Lord have mercy on them both! (V. i. 187-191)

\section{Blending of High and Low Worlds}

Farquhar's innovation can be seen also in his blending of the two worlds, the high and low. They are brilliantly combined and then made complementary to each other in several ways. First, the high and low worlds are linked through Archer, for he poses as Aimwell's servant, though a real gallant and rake. With such guise, he is able to move freely in both worlds. Secondly, the two worlds ironically complement each other in another manner. When Aimwell, together with his fake servant Archer, comes to the inn and asks Bonniface to keep his horse saddled for he may leave at a minute's warning, his command confuses the host and his daughter. Cherry immediately concludes, Ay, ten to one, father, he's a highwayman (I.i.344). Indeed, Archer and Aimwell are highwaymen of a more refined type. Their approach is different, yet the goal is the same. Still, the blending does not stop there. The attempted breaking and robbery of the house occurs at the time Archer is attempting to rob Mrs. Sullen of her virtue:

Mrs. Sullen: I hope you did not come to rob me?

Archer: Indeed, I did, but I would have taken nothing but what you might ha' spared. (V.ii.110-113)

In additions, the combining of the two worlds surfaces in other events. Archer and Aimwell, the high people, have a reserve fund of two hundred pounds to use to find a wife in France if they fail in Lichfield. Likewise, Gibbet, the real highwayman, has spared two hundred pounds to save his life at the session. Yes, sir, I can command four hundred but I must reserve two of them to save my life at the session, Gibbet says to Archer (V.iii.197-198).

\section{Portrayal of Chief Characters}

Another notable innovation of Farquhar can be seen in the portrayals of Aimwell and Dorinda, the main characters. They are portrayed as more sentimental in nature, less rakish in behavior, and to some extent exemplary characters in conduct. They are depicted as role models to be admired and imitated, and not to be ridiculed. In all measures, they are different from the stereotypes seen in other plays. The heroine Dorinda, though genuinely in love and serious in her pursuit for marriage, expresses serious fear of disillusionment in marriage. She draws upon some discouraging experiences of married couples. She reasons out, as does a rational person, before she decides. Her reflection on the unhappy marriage of Mrs. Sullen, her sister-in-law, discourages her of hurrying heedlessly into matrimony. Bewildered by what she sees, Dorinda expresses serious inhibitions before Aimwell,

But first, my lord, one word, I have a frightful example of a hasty marriage in my own family; when I reflect on it, it shocks me (V.iv.8-10).

Her frankness and genuine compassion make more probable the reform of the rake, her lover. Aimwell, hiding his real identity as a rogue, proposes to Dorinda as Lord Aimwell and his proposal wins her liking, though. Yet under the compunction of his sincere love for Dorinda, he decides to confess. His conscience is over stricken at the thought of marrying under false pretenses, and thus confesses to Dorinda his being fraud, falsely bearing his brother's title, and scheming to marry her for money, not love. Luckily, his honesty pays off. It touches Dorinda's sensitive heart, and she takes him a husband in spite of his empty coffers.

\section{Themes of Marriage and Divorce}

The Beaux Stratagem might be the first play to throw into a serious debate the question of marriage and more importantly the question of divorce. Such a peculiar debate can count as another expression of a growing shift in the purpose of English comedy. Through sensitive characters, Aimwell and Dorinda, the theme of marriage and love is, at all rate, treated more earnestly. The serious pursuit of marriage is indicated in Dorinda's suggestion that Aimwell should know her better before they get married, despite the passionate love they share:

I should not cast a look upon the multitude if you were absent. But my lord, I'm a woman; colors, concealments may hide a thousand faults in me - therefore know me better first. I hardly dare affirm I know myself in anything except my love. (V.iv.16-21)

Marriage to Farquhar has a religious overture. It is no more a trap to be avoided at all cost, as most Restoration rakes are accustomed to do. Instead, it is a heavenly ordained knot; however, this knot might be dissolved in case it contracts two individuals with different tempers and minds. In line with this, Mrs. Sullen, on one hand, ponders more often on what should be there to invigorate the holy wedlock and keep it intact, and on the other hand she ponders on what should make it dissolvable,

Wedlock we ordained by heaven's decree

But such as heaven ordained it first to be - Concurring tempers in the man and wife, 
As mutual helps to draw the load of life. (IV.i.505-508)

The same ideas can be detected in the words of Sir Charles Freeman when trying to relieve his sister from the constraint of her husband. Freeman underscores that the absence of mutual understanding and unison of minds, may give a legitimate excuse for married couple to dissolve marriage, regardless of the unreasonable yokes the society imposes on married people in tabooing divorce:

You and your wife, Mr. Guts, maybe one flesh, because you are nothing else, but rational creatures have minds that must be united. (V.i.64-66)

In other words, without mutual understanding and unison of minds, marriage should be dissolved. As critics observe, Farquhar is the first playwright to call for a better understanding of divorce and divorcees. To them, Farquhar's inclinations reach boldly beyond all precedent in Restoration comedy by bringing the concrete discussion of divorce upon the stage (Stone 350). The thought of divorce, which was tabooed in Farquhar's society, is openly debated via the exchange of Mrs. Sullen and Dorinda. Mrs. Sullen often complains of the taboo the society holds against divorce, despite the absence of what keeps marriage untied. As a wife, she has a reasonable ground to ask for divorce. The boorishness, heavy drinking, and neglect of her husband are too hard to endure (Act II, scene 1). In Act IV, Mrs. Sullen calls for a better understanding of married people's earnest inclinations for untying the matrimony knot:

Dorinda: But how can you shake off the yoke? Your divisions don't come within the reach of the law for a divorce.

Mrs. Sullen: Law! What law can search into the remote abyss of nature? What evidence can prove the unaccountable disaffections of wedlock? Can a jury sum up the endless aversion that are rooted in our souls, or can a bench give judgment upon antipathies? (IV.i.488-495)

The call of Mrs. Sullen for better understanding of divorcees has its echo in the concluding speech of Archer. While the group celebrating the wedding of Aimwell and Dorinda, and concurrently the divorce of Mrs. Sullen's and her husband, Archer thoughtfully ponders:

'T would be hard to guess which of these parties is the better pleased, the couple joined or the couple parted, the one rejoicing in hopes of an untasted happiness, and the other in their deliverance from an experienced misery. (V. iv. 330-334)

At large, the debate over marriage and divorce is meant to educate and calls for a serious review of the shackles the Law puts before people when applying for divorce.

\section{CONCLUSION}

To conclude, one may say that The Beaux Stratagem draws warm reception from theater-goers and critics. Its sure-fire comic devices, witty characters and profound insight give grand expressions to Farquhar's literary contribution to English comedy and sustain the play's lasting appeal to audiences. With its innovative particulars, it set an early premise for the approaching changes in the dramatic conventions and trends of English comedy. More crucially, it forms a gateway to move into the world of sentimentalism, or a bridge between what preceded and what came after, the Comedy of Manners and the Sentimental or Exemplary Comedy. Farquhar would remain a remarkable playwright whose play The Beaux Stratagem supplies a lasting entertainment to audiences of all ages.

\section{REFERENCES}

[1] Archer, William. Louis A. Strauss Eds. (1959). Introduction to Beaux Stratagem. New York: Hill and Wang, A Mermaid Edition.

[2] Armistead. J.M. (1984). Four Restoration Playwrights: A Reference Guide to Shadwell, Aphra Behn, Nathaniel Lee, and Thomas Otway. Boston: G. K. Hall,

[3] Bevis, Richard. (Spring 1997). Canon, Pedagogy, Prospectus: Redesigning English Drama, Restoration and EighteenthCentury 1660-1789. Comparative Drama, 31.1: 178-191.

[4] Bruce, Donald. (1974). Topics of Restoration Comedy. New York: St. Martin's Press.

[5] Canfield, Douglas J. Ed. (2001). The Broadview Anthology of Restoration and Early Eighteenth Century Drama. Lexington: University Press of Kentucky.

[6] Cordner, Michael. (2000). Playwright versus priest: profanity and the wit of Restoration comedy. In Deborah Payne Fisk (ed.) The Cambridge Companion to English Restoration Theatre. Cambridge: University Press.

[7] Dobree, Bonamy. (1966). Restoration Comedy 1660-1720. London: Oxford University Press.

[8] Evans, James E. (summer, 2003). Libertine Gamblers in Late Stuart Comedy. In Restoration and the $18^{\text {th }}$ Century Theatre Research, 18.1: 17-30. 
[9] Gosse, Edmund. (2004). A History of Eighteenth Century Studies, 1660-1780. Stockton, CA: University Press of the Pacific, Reprint

[10] Hughes, Derek. (1996). English drama, 1660-1700. Oxford: Clarendon Press.

[11] Hughes, Derek. (1997). Who Counts in Farquhar? Comparative Drama 31.1: 7-27.

[12] Kenny, Shirley Strum, ed. Introduction. The Beaux' Stratagem. By George Farquhar. Oxford: Clarendon, 1988. 131-156.

[13] Hume, Robert. (1976). The Development of English Drama in the Late Seventeenth Century. Carbondale, Illinois: Southern Illinois University Press.

[14] Jeffares, Norman. (2002). An Introduction to Oliver Goldsmith, She Stoops to Conquer. (York Notes Series) Beirut, Typo Press, 2002.

[15] Kaneko, Yuji. Ed. (1996). Jeremy Collier: A Short View of the Immorality and Profaneness of the English stage. London: Routledge.

[16] Krutch, Joseph Wood. (1967). Comedy and Conscience after the Restoration. New York: Russell and Russell

[17] McMillan. Scott. (1997). Restoration and Eighteenth-Century Comedy. New York: W. W. Norton and Company.

[18] Markley, Robert. (Spring, 2008). Introduction: Rethinking Restoration and Eighteenth-Century Drama. Comparative Drama, 42.1: 1-6.

[19] Nicoll, Allardyce. (1965). A History of English Drama. 17001900. Cambridge: University Press.

[20] Palmer, John Leslie. (2012). The Comedy of Manners. New York: Hard Press Publishing.

[21] Rose, Anthony. (1966). The Jeremy Collier Stage Controversy 1698-1726. New York: Benjamin Blom.

[22] Smith, John Harrington. (1971). The Gay Couple in Restoration Drama. New York: Octagon Books, 1971

[23] Stone, George Winchester and et al. (1975). British Dramatists: From Dryden to Sheridan. Carbondale: Southern Illinois University Press.

[24] Weber, Harold. (1986). The Restoration Rake-Hero. Transformations in Sexual Understanding in SeventeenthCentury England. Madison: University of Wisconsin Press.

[25] Wilson, John Harold. (1965). A Preface to Restoration Drama. Boston: Houghton-Mifflin. 